DOI: 10.28934/jwee19.12.pp80-86

PROFESSIONAL PAPER

\title{
Being A Female Entrepreneur - Case Study
}

\author{
Victoria Burgess ${ }^{1}$ \\ CalCampus, Ringe, United States of America
}

\section{A B S T R A C T}

The purpose of this study was to explain the factors which make an impact on the success of female CEOs. This paper takes a broad look as to what it takes to gain substantial promotions leading to executive positions, and therefore the rise in numbers. This is then followed by an interview with the Sr. Vice President of Sales at ESPN. Lastly is a look at suggestions as to why there is a sudden decrease.

KEY WORDS: female executives, promotions, successful business women

\section{Introduction}

According to research in 2018, the number of female executives fell by 25 percent (Jones, 2018). Experts say the challenges women face are bigger than their individual choices. Are the challenges the usual suspects--things like not being competitive enough, failing to chase opportunities for promotion and choosing work-life balance over high-powered jobs? Or are there larger forces at work that go beyond women's personal individual choices such as biases against women in power, mothers who work, or leaders who don't fit the mold of the people who led before them.

\footnotetext{
${ }^{1}$ E-mail: victori.3458@gmail.com
} 
For many years, it seemed as if the share of women at the top of corporate America would slowly increase over time. The number of women leading companies in the Fortune 500 had grown to 6.4 percent in 2018 , a record high, from 2.6 percent a decade earlier.However, the number of female chief executives declined 25 percent, according to Fortune's 2018 list (Jones, 2018).

This paper explores what it takes to be a successful business woman followed by an actual account via an interview with Mrs. Sweeney-Beltran.

\section{Theoretical Overview}

"Although women still face "glass ceiling" and somehow fail to achieve maximum potential, there are evidences to suggest that most countries have now realized the potential contributions women make to the nations' economic growth” (Radovic-Markovic, 2013, p. 2). Females still own and manage significantly fewer businesses than men (Achakpa and Radović-Marković, 2018). Namely, „women didn’t obtained an equal standing to men with respect to job opportunities, wage, ownership of real estate and decision-making positions in government and the business sector" (Radovic-Markovic, et. al., 2010, p. 23). In line with this, in one number of studies are explored the impact of government support on small business owners', gender, age, and race (Dincer, 2018).

According to different theoretical approaches, varieties of perspectives are offered through which we can expand and challenge our understanding of the women`s entrepreneurship (Radovic-Markovic, et.al., 2011).

\section{Discussion}

Research indicates that there were three important methods that led to the success--and increase--of business women, and therefore their rise into executive positions: recruit a sponsor within the company, strategically selfpromoter, and invest in your personal appearance. ${ }^{2}$

- Sponsors (not mentors) are people who have power and influence and are willing to use their position to advocate on your behalf. In other words, they are "in the room where it happens", and therefore can yield results in one's advancement. When Center for Talent Innovation asked professionals if they had a sponsor, only 13 percent of female professionals and just 8 percent of professionals of color 
reported having a sponsor, compared to 40 percent of their nondiverse peers. Lack of sponsorship is likely one of the reasons why there are so few female leader, and therefore successful business women, in the corporate world. It is suggested that if an individual doesn't have the necessary power and influence, or is not willing to advocate on your behalf, then he or she is not your sponsor. Furthermore, it is important to a woman's success she is an excellent protégé and gives back to your sponsors when the opportunities arise.

- Effective self-promotion is about being proud of what you worked hard to accomplish and willingly sharing those stories with others. If people start off with a neutral or negative perception of your ability, it is your responsibility to present them with positive facts about yourself, so they can form a more accurate, positive perception of you. This is particularly important for women because you they usually have to push back against negative stereotypes often associated with your gender.

- Mark Zuckerberg CEO of Facebook may wear jeans and a T-shirt to work, but you don't see Sheryl Sandberg COO of Facebook, dressing that way. Emulate the level of professional appearance of your organization's leaders to the extent that your budget will allow. Looking the part is an important component of rising through the ranks.

Besides working hard each and every day it is important for women, as suggested, to also focus on some on these matters as well. However, these are some areas that often get overlooked as per the research, and therefore put women at a disadvantage in being more strategic regarding their upward mobility and their success. Instead of being strategic they become more reactive in their career.

I took these three suggestions and posed questions to the Mrs. Sweeney-Beltran, Sr. Vice President of ESPN's Sales Department. She was on a business trip so the telephone interview was not very long. The time she gave me I truly appreciate. Her first name will not be used as requested.

First a little background about her upward mobility. Mrs. SweeneyBeltran first started out as a Junior Research Analyst in the local advertising department at NBC; after a year, she was promoted to Senior Research Analyst. Out of shear boredom (her exact words) with the tedious job of data analysis and servicing the salespeople, she became curious about sales and 
how to enter that field. She learned of an opening in the local advertising sales department at Chicago for the ABC network. She applied, got the job and moved from New York. Then she learned of a sales position that opened at ESPN, which at that time, was owned by ABC. Her love of sports propelled her into applying for that job and she got it and moved back to New York. There she moved up to sales manager, then director and on, and on. As indicated, she is now Sr. Vice President of Sales at this stellar network - which I have to add was (and kind of still is) a boys' club. Nonetheless, she did it. She is married with two teenage children.

I told her about the research and the three methods that are suggested by other successful business women. The following was interview; she will be addressed as SB:

Me: So, what is your opinion about the suggested methods? Do you agree with having a sponsor, self-promoting, and dressing the part?

SB: If it wasn't for Ron, I would not have gotten my first sales job at ABC. He literally went to bat for me to the higher ups. I'm not so sure if I actually engaged in self-promotion, but I would go into his office and discuss research data and my marketing ideas. Maybe that within itself was self-promoting. At that time, he worked at NBC and later went to ABC. We kept in touch and that's how I learned about the sales position in Chicago. I literally had no sales experience, but he had faith in me and "sold" the idea of hiring me to the powers that be sort to speak. He was a good salesperson. It's funny though, I didn't really see him as a sponsor, but I guess he was.

\section{Me: So, it seems that your creativity and ideas are what help to make your transition into sales, which eventually moved you up the ladder. Or was it business strategy.}

SB: I think it was more creativity and coming up with new concepts on marketing....and this is what Ron saw. He would always compliment me on my work and saw me more as a marketer than an analyst. He told me that marketing is very important for sales; and he would always say I would be good at it. I'm not very pushy, so sometimes I would question, and even doubt, myself about being a sales person. That being said, for me, initially it was my ideas that helped more than strategy. But as I moved up I had to incorporate a business strategy more in the plan in order to increase profits-especially when I became a Director ESPN. In my experience, the higher I moved up business strategy played a more important role...the creative ideas were left to the marketing staff and salespeople. 


\section{ME: And what about dressing for success? Did your personal appear- ance change?}

SW: I have a funny story. When I was a Junior Analyst at NBC I never got a manicure. I was young, inexperienced, and just moved to New York from Boston.... what did I know. There was another analyst that suggested that I get a manicure and voila! I've been hooked ever since. Anyway, I believe that personal appearance most definitely plays a part...especially as I moved up. I've invested in nice suits that maintain my femininity which is important for me. I don't want to look masculine...just professional.

ME: Okay, so you agree with the research. It seems that you travel a lot for your job. Do you mind if I ask if work-life balance difficult?

SB: Yes, it is. But I am very fortunate though to have a husband who has chosen to put work aside and raise the kids. It was really hard when my daughter became seriously ill. That's when the bells and whistles went off. I had to make more time for my family. Noe, because I have been at ESPN for 20 years, I have a lot of vacation time, personal time, etc. Vacations are with the family, and I make it a point to take them with me on business trips now that they are in their late teens. They enjoy all of the sporting events that ESPN has to offer. You really can't have it all and be successful at both. One of the parents has to make a sacrifice. I am very fortunate in that regard. I'll be retiring soon though.

ME: Thank you for your time. I'll wrap this up by asking if you have any advice or suggestions for those looking to advance. What is a secret to success in your opinion?

SB: Honestly what your research suggest is spot on...and now looking back is what I did but didn't realize it. However, and I don't know if this is a secret but maybe it is especially for the millennials: one has to be a good communicator and writer. And this goes for any business I believecorporate, profit, non-profit, healthcare you name it. I see this lacking very much so in this generation; technology through phones, social media, internet has put a damper on how to relate via communication — verbal and nonverbal. I teach sports marketing at Fairfield University and witness the writing and communication abilities first hand. It's kind of scary, but their abilities are lacking. In order to speak with a sponsor or self-promote one must have good communication skills. That is my advice.

The interview ended at this point after my sincere appreciation for her time and honesty. 


\section{Conclusion}

Evidence via general research, and the interview, suggest that there are ways to become a successful business woman in the corporate world in America. However, remember what was mentioned in the opening paragraph as well: that of late there is a decrease in the number of female executives. Why is this so?

In the United States alone, women statistically get more college and graduate degrees than men representing nearly half of the workforce. And yet, although women represent a substantial force in today's economy, the business world still curtails their upward mobility. It is therefore suggested that although women play by the rules in the business world with the impression that if they work hard, are diligent and committed, their skills and abilities would be recognized and rewarded, most women get discouraged after a while and give up the dream top executive job. For example, one study found that at first female employees enter the workforce with confidence, as $43 \%$ are determined to climb the corporate ladder and get a top management position. But, after a couple of years, morale drops by $60 \%$, with just $16 \%$ of women still believing they can make it to the top (Boyd,2015).

Furthermore, additional research suggests that as the foreseeable dream executive fades away, at the same time most women start considering other life goals. One study indicated that compared to men, women have more life goals that make achieving high-power positions at work seem less desirable. Therefore, women may not assume high-level positions in organizations - at least in part - because they desire other things as well: the importance of taking care of their family. I would like to add that "family" for these females does not only include their children, but their aging parents as well. Remember what Mrs. Sweeney-Beltran said in the above interview, "you really can't have it all and be successful at both". She almost paid the price and lost her daughter. She will be one of the successful business woman who will be soon drop out of this successful world, via early retirement, to be successful for her family.

\section{References}

[1] Achakpa, P. and Radović-Marković, M. 2018. Employment Women Through Entrepreneurship Development and Education in Developing Coun- 
tries, Journal of Women's Entrepreneurship and Education, 2018, No. 1-2, 17-30.

[2] Boyd, B. 2015. The pros and cons of promotions for women leaders, MultiBriefs: Exclusive. http://exclusive.multibriefs.com/content/the-pros-andcons-of-promotions-for-women-leaders/business-management-services-riskmanagement. Accessed November 10, 2018.

[3] Dincer, K. H. 2018. How Does State and Local Government Support Affect Entrepreneurs' Gender, Age and Race? Journal of Women's Entrepreneurship and Education, 2018, No. 1-2, 1-16.

[4] Jones, S. 2018. Three Unwritten Rules of the Corporate World That Women Need to Know. Women https://www.entrepreneur.com/article/322014. Accessed November 9, 2018

[5] Radović-Marković, M. 2013. Female Entrepreneurship: Theoretical Approaches, Journal of Women's Entrepreneurship and Education, 2013, No. 1-2, 1-9.

[6] Radović-Marković, M., et al. 2010. Female Employment, Journal of Women's Entrepreneurship and Education, 2010, No. 3-4, 18-27.

[7] Radović-Marković, M. 2011. Journal of Women's Entrepreneurship and Education, 2011, No. 1-2, 77-88.

[8] The Advantages of a Female CEO in Today's Business Climate. Money, Inc. https://moneyinc.com/the-advantages-of-a-female-ceo/. Accessed November 10, 2018.

Article history: $\quad$ Received: 17 April, 2019

Accepted: 18 May, 2019 